\title{
KEY PERFORMANCE INDICATOR DALAM MENGUKUR KINERJA KARYAWAN DI UNIT PENGELOLA KEGIATAN LESTARI
}

\author{
Syafrudin, Diana Djuwita dan Sri Mulyati \\ Fakultas Syariah dan Ekonomi Islam \\ Institut Agama Islam Negeri Syekh Nurjati Cirebon \\ e-mail: ujangsyaf@gmail.com,dianadjuwita@yahoo.com \\ dan srimulyati111213@gmail.com
}

\begin{abstract}
Activity Management Unit Lestari established by the inter-village meetings which choose the evaluation process by using Key Performance Indicator. As a financial institution is very sensitive so it is necessary to determine the application of performance evaluation in evaluating an employee's performance required tools or methods are precisely tailored to the institution so that performance can be measured objectively. This study used a qualitative approach is to perform observations, interviews and review documents on Activity Management Unit Lestari. Primary data in this study is data obtained directly from the information through interviews and the results obtained from interviewing employees Activity Management Unit Lestari is then performed data reduction, data presentation and then verification and confirmation data. Results Overall Performance Assessment Activity Management Unit sustainable way based on scoring criteria with the Key Performance Indicator can be seen overall performance enough, from a financial perspective is not good, from the customer perspective is good, from the perspective of internal business processes poorly and growth perspective and learning both accumulated got enough.
\end{abstract}

Keywords: Performance Measurement, Key Performance Indicator, Employee Performance.

\begin{abstract}
Abstrak
Unit Pengelola Kegiatan Lestari dibentuk oleh musyawarah antar desa yang memilih proses evaluasi dengan menggunakan Key Performance Indicator. Sebagai lembaga keuangan sangatlah sensitive maka dalam mengevaluasi sebuah kinerja karyawan diperlukan alat atau metode yang tepat disesuaikan dengan lembaga sehingga kinerja dapat diukur secara objektif. Penelitian ini menggunakan pendekatan kualitatif yaitu dengan melakukan pengamatan, wawancara dan penelaahan dokumen pada Unit Pengelola Kegiatan Lestari. Hasil Keseluruhan Penilaian Kinerja Unit Pengelola Kegiatan Lestari berdasarkan Kriteria penilaian dengan Key Performance Indicator dapat diketahui kinerja secara keseluruhan cukup, dari perspektif keuangan kurang baik, dari perspektif pelanggan baik, dari perspektif proses bisnis internal kurang baik dan perspektif pertumbuhan dan pembelajaran baik diakumulasi mendapat nilai cukup.
\end{abstract}

Kata Kunci: Pengukuran Kinerja, Key Performance Indicator, Kinerja Karyawan. 


\section{PENDAHULUAN}

Dewasa ini penelitian tentang pengembangan Sumber Daya Manusia terus semakin ditingkatkan. Oleh karena itu, setiap perusahaan masing-masing memiliki badan atau bidang khusus yang menangani permasalahan Sumber Daya Manusia. Begitu pula perusahaan lokal yang tengah berkembang agar tidak tertinggal maka perlu menerapkan manajeman yang berfokus kepada penelitian kualitas sumber daya manusia. Maka perusahan lokal ini mulai intens membangun pembinaan Sumber Daya Manusia perusahaannya, sehingga tidak selalu pembahasan tentang pengembangan produk atau peningkatan pemasaran saja yang dilihat perusahaan lokal, tetapi juga mulai meningkatkan kualitas Sumber Daya Manusianya.

Dengan melihat bagaimana Key performance Indicator (KPI) menjadi faktor penilaian kinerja sorang karyawan, maka berdasarkan uraian di atas muncul 3 (tiga) rumusan masalah, yaitu pertama, bagaimana kinerja karyawan di UPK Lestari? Kedua, bagaimana penerapan Key performance Indicator (KPI) di UPK Lestari? Dan ketiga, hambatan-hambatan apa yang dihadapi UPK Lestari dalam mengukur kinerja karyawan menggunakan KPI?

Dengan melihat rumusan masalah di atas maka tujuan penelitian ini adalah untuk mengetahui kinerja karyawan UPK Lestari. Untuk mengetahui Penerapan Key performance Indicator (KPI) di UPK Lestari. Untuk mengetahui hambatanhambatan yang dihadapi UPK Lestari dalam mengukur Kinerja Karyawan menggunakan KPI.

\section{LITERATURE REVIEW}

Penelitian tentang pengukuran kinerja karyawan dalam unit pengelola kegiatan bukanlah suatu yang baru. Berikut beberapa karya yang terdokumentasikan terkait permasalahan yang dikaji, yaitu pertama, penelitian yang dilakukan oleh Heru
Kurnianto Tjahjon $^{1}$ dalam penelitiannya yang berjudul "Penyusunan Key Performance Indicators Berbasis Balanced Scorecard" menunjukkan program kerja tahun 2010 di Rumah Sakit PKU Muhammadiyah Gombong belum sepenuhnya menerapkan prinsip Balanced Scorecard, aspek pengukuran (measurement) yang seharusnya, yaitu tidak terdapat ukuran strategik (ukuran hasil dan ukuran pemicu kinerja), dan target. Key Performance Indicator yang disusun berdasarkan Sasaran Strategik Program Kerja Tahun 2010, Perspektif pertumbuhan dan pembelajaran: indeks kapabilitas personel, kepuasan personel dan indeks lingkungan kerja islami. Perspektif proses bisnis internal: kualitas pelayanan, perbandingan kapasitas teknologi yang digunakan dengan kapasitas optimal, kecepatan pelayanan

$$
\text { Kedua, Meiliana }{ }^{2} \text { dalam }
$$

penelitiannya yang berjudul "Pengembangan Sistem Manajemen Dan Analisis Key Performance Indicator "Smart KPI" Berbasis Web", Tujuan dalam organisasi atau perusahaan dicapai melalui target-target yang ditentukan untuk setiap karyawan. Untuk mengukur pencapaian target karyawan terhadap tujuan dari organisasi atau perusahaan dapat menggunakan Key Performance Indicator (KPI). Namun, sebagian besar penerapan KPI masih dilakukan secara manual, seperti dalam hal pengisian skor, pengumpulan hasil, pemeriksaan skor, dan pembuatan laporan. Melihat kondisi tersebut, dikembangkan aplikasi yang bernama

\footnotetext{
${ }^{1}$ Heru Kurnianto Tjahjono, "Penyusunan Key Performance Indicators Berbasis Balanced Scorecard (Di Rumah Sakit PKU Muhammadiyah Gombong)". (Skripsi, Program Pascasarjana Manajemen Rumah Sakit Universitas Muhammadiyah Yogyakarta, 2014).

${ }^{2}$ Meiliana, "Pengembangan Sistem Manajemen dan Analisis Key Performance Indicator "Smart KPI" Berbasis Web". (Skripsi, Computer Science Department School of Computer Science Binus University Jakarta Barat, 2012).
} 
"Smart KPI" dengan tujuan untuk menyediakan sistem KPI yang efektif dan efisien, menyediakan data KPI yang valid untuk membantu memantau penilaian kinerja setiap karyawan dalam pencapaian target, dan membentuk struktur organisasi perusahaan dengan membentuk relasi antara atasan dengan bawahan. Aplikasi dikembangkan dengan menggunakan metode penelitian scrum yang terdiri dari backlog dan sprint. Backlog terdiri dari studi literatur, hasil penelitian atau produk sebelumnya, penyebaran kuesioner, dan wawancara IT expert. Sprint terdiri dari sprint and release planning dan actual sprint work. Hasil yang dicapai adalah sebuah aplikasi web berbasis PHP yang digunakan untuk mengelola KPI suatu organisasi atau perusahaan berdasarkan struktur user dan indikator yang diatur pada bagian back-end dan menerapkan fungsi dan proses KPI pada bagian front-end. Simpulan yang diperoleh yaitu aplikasi membantu proses pengelolaan KPI sesuai kebutuhan utama dan sudah memiliki tampilan dan kinerja yangbaik.

Ketiga, Isti Mayasari ${ }^{3}$ dalam penelitiannya yang berjudul "Penilaian Kinerja Berdasarkan Kompetensi dan KPI (Key Performer Indicator) Perusahaan Daerah Air Minum Kabupaten Semarang", Hasil penelitian menunjukkan bahwa penilaian kinerja berbasis kompetensi dan KPI yang telah disusun:

a. Dinilai lebih reliabel dan relevan karena lebih konsisten serta aspek yang dinilai lebih dapat diamati karena sesuai dengan job description, terlebih KPI bisa dimonitoring secara periodik. Ukuran dan standar lebih jelas, spesifik dan terukur. Penilaian kinerja ini juga dinilai lebih sensitif karena mampu membedakan karyawan dengan kinerja

${ }^{3}$ Isti Mayasari, "Penilaian Kinerja Berdasarkan Kompetensi dan KPI (Key Performer Indicator) Perusahaan Daerah Air Minum Kabupaten Semarang." (Skripsi, Program Pasca Sarjana Universitas Katolik Soegijapranata Semarang, 2013). tinggi maupun rendah berdasarkan nilai yang diperoleh.

b. Prosedur penilaian juga direspon dengan baik karena melibatkan karyawan yang dinilai, dan rekan kerja bukan hanya atasan langsung sehingga penilaian kinerja ini dinilai lebih obyektif.

c. Dapat digunakan sebagai dasar pengambilan keputusan yang berkaitan dengan pengembangan SDM.

d. Kelemahan dari penilaian kinerja ini adalah metode multirater yang dianggap kurang praktis karena harus melalui proses rekapitulasi dan memerlukan waktu yang lebih lama daripada penilaian satu rater. Proses monitoring KPI membuat pekerjaan karyawan jadi bertambah karena perlu pencatatan rutin tiap harinya. Meskipun demikian pihak manajemen memberikan respon positif.

Kempat, Endang Dwi Retnan ${ }^{4}$ dalam penelitiannya yang berjudul "Penentuan Key Performace Indicators Pimpinan Unit Satuan Kerja Dengan Konsep Balanced Scorecard", hasil penelitiannya menyimpulkan bahwa penentuan KPI di pimpinan unit satuan kerja telah memberikan nilai baik dari segi, kualitas pelayanan dan pencapaian target unitnya. Penentuan KPI yang dilakukan perusahaan sudah menggunakan konsep Balanced Scorcard dan menunjukan hasil yang positif serta respons yang baik di Pimpinan Unit Satuan Kerja.

Pandu Febriarso $^{5}$ dalam penelitiannya yang berjudul "Perancangan

${ }^{4}$ Endang Dwi Retnani, "Penentuan Key Performance Indicators Pimpinan unit Satuan Kerja Dengan Konsep Balanced Scorecard". (Skripsi, Sekolah Tinggi Ilmu Ekonomi Indonesia Surabaya, 2012).

${ }^{5}$ Pandu Febriarso, "Perancangan Sistem Pengukuran Kinerja dengan Metode Performance Pris". (Skripsi, Jurusan Teknik Industri Fakultas Teknik Universitas Muhammadiyah Surakarta, 2008). 
Sistem Pengukuran Kinerja Dengan Metode Performance Pri"s, Hasil rancangan menunjukkan bahwa stakeholder Hotel Arini meliputi: konsumen, tenaga kerja, supplier, pemilik/investor, serta pemerintah dan masyarakat sekitar lingkungan hotel. Sistem pengukuran kinerja memuat KPI yang meliputi 8 KPI konsumen, 6 KPI untuk employee, 6 KPI investor,6 KPI supplier, 6 KPI pemerintah dan 6 KPI untuk masyarakat di sekitar lingkungan hotel. Dari hasil implementasi sistem pengukuran kinerja dengan proses scoring system menggunakan metode OMAX menunjukkan nilai current performance indicator yang telah dicapai oleh hotel Arini adalah sebesar 6,13 . Hasil pengukuran menjadi landasan pihak manajemen mengevaluasi dan menentukan rencana kerja perbaikan sehingga harapan dari semua stakeholder dapat terpenuhi.

Melihat dari ruang lingkup penelitian terdahulu yang cakupannya luas serta objek penelitian merupakan perusahaan atau lembaga yang bertaraf nasional, ini salah satu ketertarikan peneliti memilih perusahaan yang bersifat lokal yang cakupannya masih sempit dan ingin membuktikan dengan sistem yang dilaksanakan sesuai dengan ketentuan dapat menciptakan perusahaan yang mampu bersaing dengan perusahan yang bertaraf nasional.

\section{METODOLOGI PENELITIAN}

Metode penelitian adalah suatu cara kerja yang dilakukan peneliti dengan menggunakan aturan-aturan baku dari masing-masing disiplin ilmu yang digunakan. ${ }^{6}$ Metodologi penelitian adalah cara atau strategi menyeluruh untuk menemukan atau memperoleh data yang diperlukan. $^{7} \quad$ Penelitian kualitatif

\footnotetext{
${ }^{6}$ Khaerul Wahidin dan Masyhuri Taqiyuddin, Metode Penelitian (Cirebon: STAIN Cirebon, 2002), 21.

${ }^{7}$ Irawan Soebantono, Metode Penelitian Sosial (Bandung: Rosda Karya, 1996), 9.
}

menggunakan metode kualitatif yaitu pengamatan, wawancara, atau penelaahan dokumen. $^{8}$

Dengan demikian, laporan penelitian akan berisi kutipan-kutipan data untuk memberi gambaran penyajian laporan tersebut. Data tersebut mungkin berasal dari naskah wawancara, catatan lapangan, foto, videotape, dokumen pribadi, catatan atau memo, dan dokumen resmi lainnya. ${ }^{9}$

Adapun metode yang dilakukan pada penelitian ini ialah kualitatif.

1. Pendekatan Penelitian

Dalam penelitian ini, penulis melakukan pendekatan manajemen sumber daya manusia dan prinsip prinsip operasional lembaga keuangan. Dalam hal ini tentu sangat berkaitan dalam teknis pelaksanaan kegiatan tertu diharapkan sesuai dengan prinsip operasional yang di tentukan dalam rangka mengetahui kualitas sumberdaya manusia melalui penilaian kinerja.

2. Sumber Data ${ }^{10}$

Adapun sumber data yang diperoleh dalam hal ini terdiri dari:

a. Data Primer adalah sumber data yang diperoleh secara langsung dari sumber aslinya. ${ }^{11}$

Data primer dalam penelitian ini adalah data yang diperoleh langsung dari informasi melalui wawancara dan hasil-hasil yang diperoleh dari wawancara karyawan UPK Lestari.

b. Data Sekunder

Data sekunder yang penulis terima adalah data yang diperoleh secara tidak langsung, melalui

${ }^{8}$ Lexy J. Moleong, Metodologi Penelitian Kualitatif (Bandung: Remaja Rosdakarya, 2004), 9.

${ }^{9}$ Lexy J. Moleong. Metodologi Penelitian Kualitataif, 11.

${ }^{10}$ Lexy J. Moleong, Metodologi Penelitian Kualitatif, 157-160.

${ }^{11}$ Nur Indrianto dan Bambang Supono, Metodologi Penelitian Bisnis untuk Akuntansi dan Manajemen (Yogyakart: BPFE, 2002), 146. 
dokumentasi dan buku-buku yang berhubungan dengan masalah yang dihadapi.

c. Kata-kata dan Tindakan

Kata-kata dan tindakan orangorang yang diamati atau diwawancarai merupakan sumber data utama. Sumber data utama dicatat melalui catatan tertulis atau melalui perekaman video/audio tapes, pengambilan foto, atau film.

d. Sumber Tertulis

Sumber berupa buku dan majalah ilmiah juga termasuk kategori ini. Buku, disertasi atau tesis, biasanya tersimpan di perpustakaan. Sumber tertulis lainnya adalah dokumen pribadi, yaitu tulisan tentang diri seseorang yang ditulisnya sendiri. Selain itu, sumber tertulis juga dapat berupa dokumen resmi yang biasa terdapat pada instansi-instansi pemerintah atau swasta atau lainnya yang terkait dengan lokasi tempat meneliti.

e. Foto atau Dokumentasi

Foto menghasilkan data deskriptif yang cukup berharga dan sering digunakan untuk menelaah segisegi subjektif dan hasilnya sering dianalisis secara induktif. Ada dua kategori foto yang dapat dimanfaatkan dalam penelitian kualitatif, yaitu foto yang dihasilkan orang dan foto yang dihasilkan oleh peneliti sendiri.

3. Teknik Pengumpulan Data

Adapun teknik pengumpulan data yang digunakan penulis adalah sebagai berikut:

a. Penelitian kepustakaan

Penelitian kepustakaan yaitu sumber data yang dikumpulkan dari buku kepustakaan yang berkaitan dengan objek yang diteliti. $^{12}$ Dengan cara membaca, memahami dan menginterpretasikan buku-buku, dokumen-dokumen yang berhubungan dengan pembahasan skripsi ini.

b. Wawancara

Dalam melakukan wawancara langsung, pewawancara dapat menggunakan daftar pertanyaan (quesioner), pedoman wawancara yang berisi butir-butir yang akan ditanyakan, atau tanpa kedua alat tersebut (wawancara bebas). Bagi peneliti, yang perlu disadari adalah bahwa dalam wawancara terdapat faktor-faktor yang mempengaruhi hasil wawancara, yaitu: pewawancara, key person (informan), topik penelitian (yang tertuang dalam daftar pertanyaan), dan situasi wawancara ${ }^{13}$

c. Catatan Lapangan

Pada dasarnya catatan lapangan berisi dua bagian. Pertama, bagian deskriptif yang berisi gambaran tentang latar pengamatan, orang, tindakan, dan pembicaraan. Kedua, bagian reflektif yang berisi kerangka berfikir dan pendapat peneliti, gagasan, dan kepeduliannya. ${ }^{14}$

Dalam penelitian ini, penulis menggunakan catatan lapangan yang berbentuk deskriptif dan reflektif, karena berupa gambaran yang mendeskripsikan hasil penelitian di lapangan. Selain itu, dalam penelitian ini juga terdapat analisis penulis yang merupakan refleksi dari catatan lapangan yang berbentuk pendapat, gagasan yang

\footnotetext{
${ }^{12}$ Kailan, Metode Penelitian Kualitatif Bidang Filsafat (Yogyakarta: Paradigma, 2005), 138.

${ }^{13}$ Adi Rianto, Metodologi Sosial dan Hukum (Jakarta: Granit, 2005), 73.

${ }^{14}$ Lexy J. Moleong, Metodologi Penelitian Kualitatif, 211.
} 
kemudian digambarkan melalui kerangka berfikir.

d. Penggunaan dokumen

Akhir-akhir ini orang membedakan dokumen dan record. Record adalah setiap pernyataan tertulis yang disusun oleh seseorang atau lembaga untuk keperluan pengujian suatu peristiwa atau menyajikan akunting. Dokumen ialah setiap bahan tertulis ataupun film, lain dari record, yang tidak dipersiapkan karena adanya permintaan seorang penyidik. $^{15}$ Dalam penelitian ini, penulis menggunakan media rekaman atau record sebagai alat bantu ketika wawancara. Selain itu, penulis juga menggunakan beberapa dokumen yang didalamnya berisi agenda kegiatan dan dokumentasi (foto).

4. Teknik Analisis Data

Dalam menganalisis keabsahan data, penulis menggunakan teori triangulasi. Triangulasi adalah teknik pemeriksaan keabsahan data yang memanfaatkan sesuatu yang lain dalam membandingkan hasil wawancara terhadap objek penelitian. ${ }^{16}$

Dalam teknik pengumpulan data, triangulasi diartikan sebagai teknik pengumpulan data yang bersifat menggabungkan dari berbagai teknik pengumpulan data dan sumber data yang telah ada. Bila peneliti melakukan pengumpulan data dengan triangulasi, maka sebenarnya peneliti mengumpulkan data sekaligus menguji kredibilitas data, yaitu mengecek kredibilitas data dengan berbagai teknik pengumpulan data dan berbagai sumber.

${ }^{15}$ Lexy J. Moleong, Metodologi Penelitian Kualitatif, 216-217.

${ }^{16}$ Lexy J. Moloeng, Metode Penelitian Kualitatif, 330.
Triangulasi teknik, berarti
peneliti menggunakan teknik pengumpulan data yang berbeda-beda untuk mendapatkan data dari sumber yang sama.

Sugiono dalam bukunya, Triangulasi diartikan sebagai pengecekan data dari berbagai sumber dengan berbagai cara dan berbagai waktu. $^{17}$

Menggunakan observasi partisipatif, wawancara mendalam, dan dokumentasi untuk sumber data yang sama secara serempak. Triangulasi sumber berarti, untuk mendapatkan data dari sumber yang berbeda-beda dengan teknik yang sama.

Adapun prosedur dalam penelitian ini adalah sebagai berikut:

a. Reduksi Data

Reduksi data adalah kegiatan merangkum suatu data dengan pokok permasalahan dan fokus terhadap hal-hal yang penting untuk menentukan tema dan polanya sehingga data dapat direduksi, yakni dapat memuat gambaran yang lebih jelas yang memudahkan peneliti untuk mengumpulkan data lebih lanjut

Reduksi data, yaitu merangkum, memilih hal-hal yang pokok, memfokuskan pada hal-hal yang penting, serta dicari tema dan polanya. $^{18}$

b. Penyajian Data

Penyajian data ialah mendisplaykan data yang telah direduksi yang berbentuk uraian singkat, bagan, hubungan antar kategori dan bersifat naratif.

Display data, yaitu penyajian data. Setelah mereduksi data maka selanjutnya adalah

\footnotetext{
${ }^{17}$ Sugiono, Memahami Penelitian Kualitatif (Bandung: Alfabeta, 2014), 125.

${ }^{18}$ Sugiono, Memahami Penelitian Kualitatif, 92.
} 
menyajikan data, dalam menyajikan data dapat dilakukan dengan menggunakan tabel, grafik dan sebagainya. ${ }^{19}$

c. Kesimpulan atau Verifikasi

Verifikasi adalah proses penarikan kesimpulan dan verifikasi yang berisi kesimpulan sementara yang sewaktu-waktu dapat berubah apabila tidak didukung oleh buktibukti yang kuat, namun apabila kesimpulan tersebut telah memiliki bukti yang valid dan konsisten, maka kesimpulan tersebut dapat dikemukakan. Penarikan kesimpulan dan verifikasi data (conclusion drawing/ Verification), yaitu menarik kesimpulan dan memverifikasi data atau kesimpulan yang masih bersifat sementara menjadi pasti setelah peneliti menemukan fakta dan bukti yang valid dilapangan dan data yang ada. ${ }^{20}$

Pengujian data suatu penelitian berbeda beda. Dalam penelitian kuantitatif, untuk mendapatkan data yang valid dan reabel yang diuji validitas dan reabilitasnya adalah instrument penelitiannya, sedangkan dalam penelitian kualitatif yang diuji adalah datanya. $^{21}$

\section{Jenis Penelitian}

Dalam penelitian ini bersifat deskriptif kualitatif. Metode deskriptif adalah suatu metode dalam meneliti status sekelompok manusia, suatu objek, suatu set kondisi, suatu sistem pemikiran, ataupun suatu kelas peristiwa pada masa sekarang. Tujuan dari penelitian deskriptif ini adalah untuk membuat

\footnotetext{
${ }^{19}$ Sugiono, Memahami Penelitian Kualitatif,

95.

${ }^{20}$ Sugiono, Memahami Penelitian Kualitatif, 99.

${ }^{21}$ Sugiono, Memahami Penelitian Kualitatif,
}

deskripsi, gambaran atau lukisan secara sistematis, faktual dan akurat mengenai fakta-fakta, sifat-sifat serta hubungan antarfenomena yang diselidiki. ${ }^{22}$

6. Instrumen Penelitian

Dalam penelitian kualitatif, yang menjadi instrumen (alat utama) dalam mengumpulkan data adalah peneliti itu sendiri, karena hanya manusia (peneliti) yang dapat berinteraksi dengan key person (informan) atau objek lain. Selain itu, hanya peneliti (manusia) juga yang mampu memahami hal-hal yang terjadi di lapangan yang berupa fakta atau kenyataan kongkrit melalui indra penglihatan, indra pendengaran, daya berfikir dan lain sebagainya. Oleh karena itu, peneliti juga berperan serta dalam pengamatan.

Secara teori, fungsi peneliti kualitatif sebagai human instrumen adalah untuk menetapkan fokus penelitian, memilih informan sebagai sumber data, melakukan pengumpulan data, menilai kualitas data, analisis data, menafsirkan data dan membuat kesimpulan atas temuannya. $^{23}$

\section{KONSEP DASAR}

Key Performance Indicators (KPI) ialah suatu pernyataan tentang suatu posisi atau jabatan yang terukur. Berasal dari visi perusahaan, cara pencapaian visi melalui misi. Kemudian dijabarkan oleh setiap departemen. Dari misi kemudian dapat menghadirkan system kerja yang kemudian dilanjutkan dengan sasaran (outcome) dari tugas, dengan memiliki nilai ambang batas (threshold) untuk membedakan antara nilai target dengan nilai aktual. Sehingga diharapkan agar organisasi tidak sia-sia menggaji karyawan, dan karyawan dapat selalu mengetahui tugas dan tanggung

\footnotetext{
${ }^{22}$ Moh. Nazir, Metode Penelitian (Bogor: Ghalia Indonesia, 2011), 54.

${ }^{23}$ Sugiyono, Metode Penelitian Bisnis (Bandung: Alfabeta, 2001), 97.
} 
jawabnya karena harus mencapai target. Dengan adanya KPI perusahaan dapat menghasilkan reward dan punishment. ${ }^{24}$

Setiap perusahaan memiliki visi dan misi serta tujuan yang berbeda dengan perusahaan lainnya, hal itu terjadi karena terdapat perbedaan terhadap masing-masing kebutuhan perusahaan. Oleh karena itu, sebelum menetapkan KPI, perusahaan harus melakukan beberapa persiapan berikut: ${ }^{25}$ Menetapkan tujuan yang hendak dicapai. Memiliki bisnis proses yang telah terdefinisi dengan jelas.Menetapkan ukuran kuantitatif dan kualitatif sesuai dengan tujuan yang hendak dicapai. Memonitor setiap kondisi yang terjadi serta melakukan perubahan yang diperlukan guna mencapai tujuan yang telah ditetapkan, baik tujuan jangka pendek maupun tujuan jangka panjang.

KPI membutuhkan perencanaan yang matang. Selain itu juga harus didukung oleh ketersediaan data dan informasi yang akurat serta konsisten. Di sinilah peran penting sistem informasi bagi sebuah perusahaan. KPI dibedakan menjadi lagging indicator dan leading indicator. Dalam kamus ekonomi, pengertian dari leading indicator (indikator periode mendatang) adalah suatu rangkaian data statistik periode lalu yang menunjukkan kecenderungan yang mencerminkan perubahan-perubahan pada waktu mendatang dalam beberapa sektor ekonomi terkait atau sebagai sinyal kejadian di masa depan. ${ }^{26}$ Singkatnya, leading indicator merupakan beberapa variable ekonomi yang bergerak mendahului pergerakan variabel utama ekonomi. Lagging indicator atau yang disebut juga sebagai indikator periode lalu adalah suatu

\footnotetext{
${ }^{24}$ Tjutju Yuniarsih dan Suwatno, Manajemen Sumber Daya Manusia Teori, Aplikasi dan Isu Penelitian (Bandung: Alfabeta, 2009), 32.

${ }^{25}$ R. N. Anthony and V. Govindrajan, Management Control System (New York: Mc. GrawHill-Irwin, 2001), 42.

${ }^{26}$ V. A. Laksmita, Analisis Pengukuran Kinerja Perusahaan dengan Metode Balanced Scorecard (Semarang: Universitas Diponegoro, 2011), 29.
}

rangkaian data statistik pada periode lalu dan telah menunjukkan kecenderungan yang mencerminkan perubahan-perubahan pada waktu lalu dalam beberapa sektor ekonomi yang saling berkaitan. ${ }^{27}$

Key Performance Indicator atau indikator kinerja kunci merupakan Indikator yang memberikan informasi sejauh mana kita telah berhasil mewujudkan target kerja yang telah kita tetapkan. Beberapa syarat dari indikator key performance adalah indikator key performance indicator harus bersifat terukur, harus bisa dihitung/diukur, Indikator key performance indicator juga merujuk pada hasil kerja kita (output kerja), ukuran keberhasilan harus menunjukkan indicator kinerja yang jelas, spesifik dan terukur (measurable), Ukuran keberhasilan harus dinyatakan secara eksplisit dan rinci sehingga menjadi jelas apa yang diukur. Manfaat dari key performance indicator: Pengelolaan kinerja pegawai melalui sistem KPI memberikan sejumlah manfaat positif bagi perusahaan, ${ }^{28}$ diantaranya:

1. Melalui metode key performance indicator maka kinerja setiap pegawai dapat dievaluasi secara lebih obyektif dan terukur, sehingga dapat mengurangi unsur subyektivitas yang sering terjadi dalam proses penilaian kinerja pegawai.

2. Melalui penentuan key performance indicators secara tepat, setiap pegawai juga menjadi lebih paham mengenai hasil kerja yang diharapkan darinya. Hal ini akan mendorong pegawai bekerja lebih optimal untuk mencapai target kinerja yang telah ditetapkan.

3. Melalui penetapan key performance indicators yang obyektif dan terukur, maka proses pembinaan kinerja pegawai dapat dilakukan secara lebih transparan dan sistematis.

${ }^{27}$ V. A. Laksmita, Analisis Pengukuran Kinerja Perusahaan dengan Metode Balanced Scorecard, 30.

${ }^{28}$ Wibowo, Manajemen Kinerja (Jakarta: PT. Raja Grafindo Persada, 2008), 45. 
4. Hasil skor key performance indicators yang obyektif dan terukur juga dapat dijadikan dasar untuk pemberian reward dan punishment pegawai. Dengan demikian, pegawai yang kinerjanya lebih bagus akan mendapat reward, sebaliknya yang kerjanya kurang baik akan mendapat punishment.

Key Performance Indicator atau indikator kinerja kunci merupakan Indikator yang memberikan informasi sejauh mana kita telah berhasil mewujudkan target kerja yang telah kita tetapkan. Beberapa syarat key performance indicator harus bersifat terukur, harus bisa dihitung/diukur, Indikator key performance indicator juga merujuk pada hasil kerja kita (output kerja), ukuran keberhasilan harus menunjukkan indicator kinerja yang jelas, spesifik dan terukur (measurable), Ukuran keberhasilan harus dinyatakan secara eksplisit dan rinci sehingga menjadi jelas apa yang diukur. ${ }^{29}$

Pengelolaan kinerja pegawai melalui sistem KPI memberikan sejumlah manfaat positif bagi perusahaan, ${ }^{30}$ yaitu:

1. Melalui metode key performance indicator maka kinerja setiap pegawai dapat dievaluasi secara lebih obyektif dan terukur, sehingga dapat mengurangi unsur subyektivitas yang sering terjadi dalam proses penilaian kinerja pegawai.

2. Melalui penentuan key performance indicators secara tepat, setiap pegawai juga menjadi lebih paham mengenai hasil kerja yang diharapkan darinya. Hal ini akan mendorong pegawai bekerja lebih optimal untuk mencapai target kinerja yang telah ditetapkan.

3. Melalui penetapan key performance indicators yang obyektif dan terukur, maka proses pembinaan kinerja

${ }^{29}$ Tjutju Yuniarsih dan Suwatno, Manajemen Sumber Daya Manusia Teori, Aplikasi dan Isu Penelitian, 26.

${ }^{30}$ Tjutju Yuniarsih dan Suwatno, Manajemen Sumber Daya Manusia Teori, Aplikasi dan Isu Penelitian, 26. pegawai dapat dilakukan secara lebih transparan dan sistematis.

4. Hasil skor key performance indicators yang obyektif dan terukur juga dapat dijadikan dasar untuk pemberian reward dan punishment pegawai. Dengan demikian, pegawai yang kinerjanya lebih bagus akan mendapat reward, sebaliknya yang kerjanya kurang baik akan mendapat punishment.

Dari uraian di atas maka peneliti memfokuskan penelitian ini terhadap Key Performance Indicator untuk meningkatkan kinerja pegawai.

\section{PEMBAHASAN DAN DISKUSI}

Menurut teori dan hasil wawancara serta dokumen-dokumen UPK Lestari, maka peneliti dapat menyusun keterkaitan visi, misi, dan rencana strategis perusahaan dengan keempat perspektif Balance Scorecard. Visi: Mewujudkan kesejahteraan masyarakat desa melalui pengembangan usaha ekonomi dan pelayanan social. Misi: meningkatkan pendapatan masyarakat dan mengurangi beban pengeluaran rumah tangga miskin (RTM) dengan cara menggerakan perekonomian perdesaan melalui pelayanan di bidang keuangan dan pelayanan social.

Perspektif yang digunakan adalah sebagai berikut:

1. Perspektif keuangan, indikatornya adalah pertumbuhan asset produktif, peningkatan surplus atau laba, optimalisasi asset produktif.

2. Perspektif pelanggan, indikatornya adalah pangsa pasar, akuisisi pelanggan, loyalitas pelanggan.Perspektif proses bisnis internal, indikatornya adalah: inovasi dan pengembangan produk, rasio biaya, penyaluran pembiayaan, pendampingan kelompok.Perspektif pertumbuhan dan pembelajaran, indikatornya adalah: produktifitas karyawan, kepatuhan rencana kerja, pelatihan karyawan. 
Cara Pengukuran dalam BSC skor diukur secara harfiah seimbang antara perspektif yang satu dengan perspektif lainnya, dengan tolok ukur masing-masing perspektif. Menurut Mulyadi, Kriteria keseimbangan digunakan sebagai pedoman untuk memberikan skor pada setiap perspektif Balance Scorecard. Peneliti memberikan skor 1 untuk ukuran strategis yang mengalami perbaikan pada tahun berikutnya. Skor 0 untuk ukuran strategis yang mengalami perubahan tetapi tidak memberi dampak perbaikan atau penurunan kinerja yang berarti. Sedangkan skor -1 diberikan untuk strategis yang mengalami penurunan pada tahun berikutnya sehingga memberikan penurunan kinerja.

Untuk perhitungan hasil skor, peneliti menghitung dengan cara membagi jumlah skor yang diperoleh dengan jumlah skor keseluruhan. Kemudian nilai yang diperoleh dijadikan acuan untuk menilai kinerja . Nurhayati dalam Nurul Umam menyatakan bahwa kinerja dikatakan "baik" bila nilai yang diperoleh lebih besar dari 0,6 , "cukup" bila nilai yang diperoleh pada rentang 0-0,6, sedangkan "kurang baik" bila nilai yang diperoleh kurang dari 0 .

1. Perspektif Keuangan: Pertumbuhan Asset produktif.

Ukuran strategisnya adalah prosentase perkembangan asset produktif. Semakin besar perkembangannya maka kinerja UPK semakin baik. Jumlah asset produktif diketahui dari neraca microfinance per 31 Desember 2015 sebesar Rp. 1.797.219.893 dan 31 Desember 2016 mengalami penurunan menjadi RP. 1.784.518.084.

Dari hasil analisa dapat diketahui bahwa perkembangan asset Produktif menurun pada tahun berikutnya yaitu Tahun 2016 sebesar $0,71 \%$. Sedangkan Tahun 2015 asset produktif sebesar 0,73\% Dengan demikian Pertumbuhan Asset Produktif UPK Lestari mendapat skor -1. Peningkatan Surplus/laba, Peningkatan surplus/laba dapat diketahui dengan membandingkan jumlah surplus berjalan di neraca microfinance per 31 Desember dari tahun 2015 dan 2016. Adapun laba pada tahun 2015 sebesar Rp 119.822.696 dan pada tahun 2016 sebesar $\mathrm{Rp}$ 112.863.887.

Berdasarkan hasil analisa dapat diketahui bahwa keuntungan mengalami penurunan pada tahun berikutnya dan mendapat skor -1 . Optimalisasi Asset Produktif dimaksudkan agar seluruh asset produktif yang dimiliki dapat digunakan semaksimal mungkin untuk memperoleh pendapatan. Dari hasil analisa menunjukan bahwa lembaga tersebut tidak mengalami kemajuan, bahkan terjadi kemunduran. Karena optimalisasi asset produktif menurun dengan demikian mendapat skor -1 . Menandakan masih banyak asset produktif yang belum dioptimalkan penggunaannya. Perspektif keuangan sebesar -1, sehingga dapat disimpulkan bahwa kinerja perspektif keuangan UPK lestari adalah Menurun

2. Perspektif Pelanggan: Pangsa Pasar.

Segmen pasar UPK Lestari adalah kelompok yang beranggotakan perempuan yang memiliki usaha skala mikro, diutamakan anggota RTM (Rumah tangga Miskin). Dari laporan perkembangan kelompok, peneliti mendapatkan bahwa selama ini kelompok yang menjadi nasabah sebagian besar adalah kelompok Simpan Pinjam Perempuan (SPP). Pada tahun 2015, jumlah 65 kelompok, dan 9 kelompok adalah Unit Ekonomi Produkrif (UEP). Sedangkan pada tahun 2016, jumlah kelompok meningkat signifikan menjadi 92 kelompok, 23 Unit Ekonomi Produkrif (UEP), sisanya kelompok Simpan Pinjam Perempuan (SPP). Terjadi fluktuasi terhadap jumlah kelompok, namun segmen pasarnya terus meningkat. Dengan demikian pangsa pasar mendapat skor 1. Akuisisi Pelanggan Pengukuran 
kinerja pada perspektif ini dilakukan dengan cara membandingkan jumlah pelanggan dari tahun 2015 ke tahun 2016. Jika jumlah kelompok meningkat pada tahun berikutnya maka perusahaan dinilai mampu memperoleh pelanggan baru.

Berdasarkan laporan perkembangan kelompok per 31 Desember 2015 dan 2016 diketahui jumlah kelompok meningkat di tahun 2016. Dengan demikian akuisisi pelanggan mendapatkan skor 1 . Loyalitas Pelanggan UPK Lestari memiliki kriteria tersendiri untuk mengetahui tingkat loyalitas pelanggan. Yaitu dengan meningkatnya tingkat pengembalian pinjaman tepat waktu. Dari data yang didapatkan diketahui bahwa dana banyak yang berada di kelompok pada tahun 2015 sebesar $\mathrm{Rp}$ 1.311.167.000 dan mengalami kenaikan pada tahun 2016 menjadi Rp. 1.668.183.500.

Dengan demikian loyalitas nasabah mendapat skor 1. Dari uraian di atas dapat dilakukan penghitungan yang menghasilkan nilai 1 . Dengan demikian dapat disimpulkan bahwa kinerja Perspektif Pelanggan UPK Lestari adalah baik.

3. Perspektif Proses Bisnis Internal: Inovasi dan Pengembangan Produk.

Dari dua produk pinjaman yang ditawarkan UPK antara Simpan Pinjam Perempuan (SPP) dan Unit Ekonomi Produktif (UEP). Seharusnya UPK melakukan pengembangan produk yang inovatif yang bisa memperbanyak jumlah dana yang digulirkan dan mempercepat perguliran. Dengan demikian inovasi dan pengembangan produk mendapat skor 0. Rasio Biaya, Penghitungan rasio biaya digunakan untuk mengetahui efisiensi penggunaan dana oleh UPK dalam menjalankan operasinya untuk meningkatkan pendapatan. Rasio biaya dapat diketahui dengan membandingkan total biaya selama satu tahun dengan total pendapatan jasa satu tahun. Data berikut berdasarkan laporan laba/rugi UPK tahun 2015 dan 2016.

Berdasarkan hasil analisa dapat diketahui rasio biaya dari tahun 2015 sampai tahun 2016 terus meningkat. Ini dapat diartikan perusahaan belum dapat melakukan efisiensi terhadap biaya yang dikeluarkan. Dengan demikian rasio biaya mendapat skor -1 . Penyaluran Pembiayaan, Penyaluran Pembiayaan yang dilakukan oleh UPK Lestari meliputi membuat dan melaksanakan aturan perguliran yang sesuai dengan prinsip PNPM. Yaitu memuat persyaratan kelayakan kelompok, aturan jasa pinjaman, jangka waktu, jadwal angsuran, serta pengelolaan pinjaman bermasalah. UPK sudah melaksanakan perguliran sesuai dengan aturan yang berlaku. Bahkan UPK juga memfasilitasi calon nasabah dalam mempersiapkan dokumen pengajuan pinjaman. Sedangkan dalam realisasi pinjaman UPK butuh waktu paling lama dua minggu. Dengan demikian pengelolaan pinjaman mendapat skor 0 . Pendampingan Kelompok.

Selain melestarikan asset perguliran, UPK mempunyai tugas lain yang sangat penting yang berkaitan dengan pemberdayaan masyarakat. UPK Lestari juga melaksanakan fasilitasi kelompok, baik yang berkaitan dengan administrasi pinjaman kelompok maupun usaha yang dijalankan kelompok. Namun sampai saat ini yang berhasil dilakukan adalah pendampingan administrasi, belum sepenuhnya berhasil dalam pendampingan usaha kelompok. Dengan demikian layanan purna jual mendapat skor 0 .

Dari uraian diatas, dapat dilakukan penghitungan yang menghasilkan nilai $-0,25$ untuk Perspektif Proses Bisnis Internal. 
Dengan demikian dapat disimpulkan bahwa kinerja perspektif Proses Bisnis Internal UPK Bina mandiri adalah kurang baik.

4. Perspektif Pertumbuhan dan Pembelajaran: Produktivitas Karyawan. Ukuran strategis pada perspektif ini adalah mengukur seberapa besar keuntungan yang berhasil didapat oleh perusahaan. Produktivitas karyawan menunjukkan besarnya perolehan surplus tiap tahun yang dihasilkan oleh setiap karyawan dalam satu tahun.

Dari hasil analisa dapat diketahui bahwa perolehan surplus menurun pada tahun berikutnya. Dengan demikian produktivitas karyawan mendapat skor 1. Kepatuhan Rencana Kerja, Setiap berakhir tahun anggaran UPK melakukan laporan pertanggung jawaban kepada Musyawarah Antar Desa. Sekaligus menyusun dan menetapkan rencana untuk tahun anggaran berikutnya. Dalam pelaksanaannya, UPK selalu memperhatikan rencana kerja yang sudah dibuat. Tidak ada kegiatan yang terlewatkan, semua sesuai rencana walaupun kadang-kadang ada kegiatan yang tiba-tiba harus dilaksanakan tapi tidak ada di rencana kerja, biasanya kegiatan tersebut berhubungan dengan Asosiasi UPK se-Kabupaten Indramayu. Sedangkan untuk bidang keuangan, UPK menggunakan biaya operasional tidak lebih dari yang dianggarkan. Biasanya yang bertambah adalah anggaran untuk pembiayaan yang terkadang nasabah mengajukan pembiayaan lebih besar atau bertambahnya kelompok baru.

Dari uraian hasil wawancara dengan ketua UPK tersebut dapat disimpulkan kepatuhan rencana kerja UPK cukup baik. Dengan demikian kepatuhan rencana kerja mendapat skor 1. Pelatihan Karyawan, Untuk meningkatkan kualitas dan motivasi karyawan, maka lembaga mengadakan pelatihan karyawan yang diadakan bersama dengan UPK se Kabupaten Indramayu. Pelatihan tersebut diadakan setiap tahun anggaran. Dengan demikian Pelatihan karyawan mendapat skor 1 .

Berdasarkan data di atas dapat dilakukan perhitungan dan menghasilkan nilai 1. Dengan demikian dapat disimpulkan bahwa kinerja Perspektif Pertumbuhan dan Pembelajaran UPK Lestari.

\section{KESIMPULAN}

Dari hasil penelitian terdapat tiga kesimpulan, pertama kinerja karyawan UPK Lestari secara keseluruhan baik, yang di tunjukan oleh indikator produktivitas karyawan menurun, dari indikator kepatuhan rencana kerja meningkat, dari indikator pelatihan karyawan meningkat.

Kedua hasil Keseluruhan Penilaian Kinerja UPK Lestari berdasarkan Kriteria penilaian dengan KPI dapat diketahui kinerja secara keseluruhan cukup, dari perspektif keuangan kurang baik, dari perspektif pelanggan baik, dari perspektif proses bisnis internal kurang baik dan perspektif pertumbuhan dan pembelajaran baik diakumulasi mendapat nilai "cukup" Dengan demikian apabila kinerja suatu perusahaan dikatakan baik, belum tentu semua aspek baik. Itulah mengapa penting dilakukan penilaian kinerja pada masingmasing aspek agar lebih fokus di sisi mana yang masih perlu dibenahi dan ditingkatkan.

Ketiga pelaksanaan penilaian kinerja UPK Lestari mengalami hambatanhambatan dari komitmen pimpinan tidak kosisten, SDM kurang mempuni/kurang memahami KPI, tindaklanjut dan proses penyusunan KPI yang lamban, menganggap penilaian hanya sebagai bentuk formalitas. 


\section{DAFTAR PUSTAKA}

Tjahjono, Heru Kurnianto. "Penyusunan Key Performance Indicators Berbasis Balanced Scorecard (Di Rumah Sakit PKU Muhammadiyah Gombong)". Skripsi, Program Pascasarjana Manajemen Rumah Sakit Universitas Muhammadiyah Yogyakarta, 2014.

Meiliana. "Pengembangan Sistem Manajemen dan Analisis Key Performance Indicator "Smart KPI" Berbasis Web". Skripsi, Computer Science Department School of Computer Science Binus University Jakarta Barat, 2012.

Mayasari, Isti. "Penilaian Kinerja Berdasarkan Kompetensi dan KPI (Key Performer Indicator) Perusahaan Daerah Air Minum Kabupaten Semarang". Skripsi, Program Pasca Sarjana Universitas Katolik Soegijapranata Semarang, 2013.

Retnani, Endang Dwi. "Penentuan Key Performance Indicators Pimpinan unit Satuan Kerja Dengan Konsep Balanced Scorecard'. Skripsi, Sekolah Tinggi Ilmu Ekonomi Indonesia Surabaya, 2012.

Febriarso, Pandu. "Perancangan Sistem Pengukuran Kinerja dengan Metode Performance Pris". Skripsi, Jurusan Teknik Industri Fakultas Teknik Universitas Muhammadiyah Surakarta, 2008.

Yuniarsih, Tjutju dan Suwatno. Manajemen Sumber Daya Manusia Teori, Aplikasi dan Isu Penelitian. Bandung: Alfabeta, 2009.

Amthony, R. N. and V. Govindrajan. Management Control System. New York: Mc. Graw-Hill-Irwin, 2001.

Laksmita, V. A. Analisis Pengukuran Kinerja Perusahaan dengan Metode Balanced Scorecard. Semarang: Universitas Diponegoro, 2011.

Wibowo. Manajemen Kinerja. Jakarta: PT. Raja Grafindo Persada, 2008.
Wahidin, Khaerul dan Masyhuri Taqiyuddin. Metode Penelitian. Cirebon: STAIN Cirebon, 2002.

Soebantono, Irawan. Metode Penelitian Sosial. Bandung: Rosda Karya, 1996.

Moleong, Lexy J. Metodologi Penelitian Kualitatif. Bandung: Remaja Rosdakarya, 2004.

Indrianto, Nur dan Bambang Supono. Metodologi Penelitian Bisnis untuk Akuntansi dan Manajemen. Yogyakart: BPFE, 2002.

Kailan. Metode Penelitian Kualitatif Bidang Filsafat. Yogyakarta: Paradigma, 2005.

Rianto, Adi. Metodologi Sosial dan Hukum. Jakarta: Granit, 2005.

Sugiono. Memahami Penelitian Kualitatif . Bandung: Alfabeta, 2014.

Nazir, Moh. Metode Penelitian. Bogor: Ghalia Indonesia, 2011.

Sugiyono. Metode Penelitian Bisnis. Bandung: Alfabeta, 2001. 